
Yıl 17
Güz 2019
Sayı 27
Ss. $127-141$

Geliş Tarihi: 24.07.2019

Kabul Tarihi: 14.10.2019

\title{
XVI-XVII. Yüzyıl Osmanlı Katl Davalarında Bürokratik Prosedür: Mahkeme ve Dîvân Kayıtları Üzerine Bir İnceleme
}

Ekrem TAK*

\begin{abstract}
Özet
Osmanlı hukuk literatüründe ceza davaları ve bu davaların muhakeme usulleri, infaz şekilleri, mahkeme sonuçlarının kayda geçirilmesi ve bu süreçlerde uygulanan bürokratik prosedür bir bütün olarak incelenmemiştir. Alanın önemli sorunlarından biri de ceza hukukunun ana konularından olan had ve kısas davalarında hâkim kararlarının sicillere kaydedilip edilmediği veya kadıların had ve kısas davalarında nihai kararı verme yetkilerinin olup olmadiğıdır. Bazı hukukçu ve hukuk tarihçileri kadıların mahkemelerde gördükleri davaların sonucunda, verilen hükmün erken dönemlerde kaydedilmemesinden yola çıkarak kadıların sadece mahkeme safahatını tescil edip bu tür davalarda hüküm vermedikleri kanaatine varmışlardır. Bu çalışmada Osmanlı mahkeme kayıtları ve Divan-ı Hümayun defter verileri esas alınarak İslam ceza hukukunun had ve kisas cezasi gerektiren suçlardan birisi olarak kabul ettiği katl davalarının örfì ve şerî hukuktaki yeri ve Osmanl mahkemelerinde davanın nasıl görüldü̈̆̈̈, nasıl hüküm verildiği, verilen hükmün kayıt şekli ve cezaların örfì ve şerî hukuka göre infaz edilip edilmediği incelenecektir.
\end{abstract}

Anahtar kelimeler: Şeriye Sicili, Katl, Mahkeme, Kadı, Dîvân-ı Hümâyûn

The Bureaucratic Procedure in the Ottoman Homicide Cases in 16-17th Centuries: A Study on the Records of the Imperial Concil and Court Records

\begin{abstract}
In Ottoman law, criminal cases and their court proceedings, methods of punishments, the recording procedure of court results and bureaucratic procedures in these processes have not been examined as a whole. One of the major questions of the field is whether the judges'verdicts were registered in the court records or whether the judges had the power to reach the final verdic tin the hadd and klsas (retaliation) cases, which are the main subjects of criminal law. On the basis of the fact that the judges did not record the verdicts after trials in the courts in early times, some lawyers and legal historians have concluded that the judges only registered the proceedings and did not receive a verdict in criminal cases. Based on Ottoman court records and Imperial Council registers (Divan-ı Humayun registers), this study will examine the position of
\end{abstract}

\footnotetext{
* Dr. Öğr. Üyesi, İstanbul Medeniyet Üniversitesi Edebiyat Fakültesi Bilgi ve Belge Yönetimi Bölümü. ekrem.tak@medeniyet.edu.tr
} 
homicide cases in the Islamic and common laws, which were accepted as one of the offences which required the punishment of hadd and kisas (retaliation) according to Islamic law. It will be also examined how the cases were tried and adjudicated, how was the procedure of recording the judgements and whether the levied punishments were applied in line with Islamic and common laws.

Key words: Court register, Capital punishment, Court, Qadi (Judge), Imperial Council

Osmanlı hukukunda katl davaları örfî ver șerî hukuk alanına giren ve yargı mercii ve yargılama yetkisi bakımından hem Divân-1 Hümâyûn hem de Osmanlı mahkemelerini ilgilendiren mühim bir mesele olduğundan birçok cihetden incelemeyi gerektirmektedir. Bu sebeple bu makale katl davalarının şerî ve örfî hukukta nasıl ele alındığını inceleyen bir girişle başlamakta ve katl davalarının cezaî müeyyidelerinin uygulanış şekli üzerinde durmaktadır.

Osmanlı adalet sisteminin şerî ve örfî-sultanî hukuk olmak üzere ikili bir yapıda olması hukukî dualizmin menşeini oluşturmuş ve suçlar da buna göre hem şerî hem örfî hukukun ilgi alanına girmiştir. Şerî ceza hukukunda cezalar bilindiği gibi had ${ }^{1}$, kısas ${ }^{2}$ ve tazir $^{3}$ olmak üzere üçe ayrılmıştır. Katl davaları şerî hukukta kısas cezası altında incelenir. Kısas cezasının düşmesi veya afvı durumunda suçlunun diyet ödemesi veya bedelsiz salıverilmesi de mümkündür. Örfî hukukta ise cezaî müeyyideler, Sultanın teşrî̂ yetkilerini kullanarak belirlediği ve nişancı ve müftü tarafından kaleme alınmış hukukî metinler halinde düzenlenmiş olup katlden başlamak üzere hapis cezası, kürek cezası, para cezası v.s. şeklinde uygulanmıştır. ${ }^{4}$

1- Şer‘î hukukta suçlar cezanın ağırlığına veya bunların şer‘î kaynaklarda belirlenmiş olup olmamasına göre had, kısas, tazir olarak üçe ayrılmaktadır. Had cezaları dinen yasak kılınmış fiillerin işlenmesi halinde verilen cezalardır. Bu suçlar hırsızlık, zina, zina iftirası (kazf), yol kesme (hırabe), şarap içme-sarhoşluk, irtidat (dinden dönem) ve devlete isyan olmak üzere yedi tanedir. Bununla birlikte sihir, peygamberlere sövmek, zındıklık, namazı terk etmek, orucu terk etmek gibi fiilleri de had cezası kapsamına dahil ederek bu sayıyı on üçe kadar çıkaran hukukçular da vardır. (Ali Bardakoğlu, "Ceza”, Türkiye Diyanet İslam Ansiklopedisi (DİA), 1993, c.VII, s.474.)

2- Kısas cezası insan canına ve vücut azalarının bütünlügüüne karşı işlenen kasıtlı suçların, işlenen suçun mahiyetine eşit olarak birebir aynı şekilde verilen cezadır. Konumuz itibariyle de kısasen ölüm cezası da kasten adam öldürmenin cezası olarak verilmektedir. Ancak bu cezanın verilmesi için gerekli bazı şartların yerine gelmesi gereklidir. Bunlar suçlunun akil baliğ olması, suçun sabit olması, maktulün varislerinin kısas talep etmeleridir. Şeriate göre varislerden biri kısas istemezse diğerleri istese bile suçlu idam edilmez. (Şamil Dağc1, "Kisas", Di், 2002, c.XXV, s.488.)

3- Tazir cezaları ise, alt üst ve üst sınırları şeriat tarafından belirlenmiş ancak miktarının devlet başkanına bırakıldığı suçlar için verilen cezalardır. Had, kısas ve diyet suçlarının cezası belli ve sabittir. Tazir cezası ise alt ve üst sınırları belli olmakla birlikte hükmü vereninin idaresine göre esnek bırakılmıştır. Ancak kadı kendi takdiri ile istediği konuları suç olarak kabul edip bunun karşılığında istediği cezayı veremez. Kadı ancak kanunda kendisi için belirlenen bu alt-üst sınırlar içinde takdir hakkını kullanır. (Tuncay Başoğlu, "Tazir", DİA, 2011, c.XL, s.198.)

4- Bazı hukukçular Osmanlı hükümdarlarının siyaseten katl suretiyle uyguladıkları cezalandırma şeklini hükümdarların tazir cezası olarak ölüm cezası verdikleri şeklinde yorumlamışlardır. Ancak tazir cezası 
Osmanlı kânunnâmelerinde katl ile ilgili fiillerin cezaî müeyyidelerini tespit eden hükümler, örfî hukukun idarî ve siyasî boyutuyla alakalı olup şerî yaptırımlar hakkında bir bilgi içermez. Dolayısıyla katl cezaları şerî hukukun belirlediği cezalar kapsamında değerlendirilir ve suçun nitelik ve mahiyetine göre kısas veya diyet cezalarından herhangi biriyle karşılık görür. Fakat burada katl fiilinin idârî ve siyasî neticelerini ayrıca değerlendirmek gerekir. Çünkü öldürme fiilinin sadece bir bireyi ve ailesini ilgilendirdiği durumlarda cezaî müeyyidelerin takdîri tamamen şerî hukukun öngördüğü sınırlar içinde verilir. Fakat öldürme fiili kamuyu ilgilendirecek şekilde eşkıyalık, yol kesme gibi bir mahiyet kazanmıșsa bu noktada kadı yargılamayı yaptıktan sonra durumu bir sicil sureti veya arzla Divân-1 Hümâyûn'a bildirmekte ve cezaî müeyyidenin takdîrini Divân yapmaktadir.

\section{Katl Davalarının Mahkeme Sicillerine Yansıması ve Osmanlı Kadılarının Katl Davalarındaki Salahiyeti}

XV-XVI. yüzyıla ait şeriye sicillerinde, İslam ceza hukukunun hadlerle ilgili müeyyidelerine ait kadı kararları genellikle yer almamıştır. Bu sebeple bazı araştırmacılar kadıların ceza davalarında sadece tespit amaçlı kayıtlar tuttuğunu ve davaların Dîvân'a intikal ettiğini fakat bu hususta Dîvân'a ait defterlerde de verilen hüküm ve cezanın uygulanışı hakkında bilgi bulunmadığını ifade eder. ${ }^{5}$

Hukuk tarihi çalışmalarının birçoğunda kadıların verdiği had ve kısas hükümlerinin Divan’a gönderilerek burada görüşüldüğü, padişahın onayı alındıktan sonra hükmün

olarak ölüm cezasının verilmesi fikıh uleması arasında fikir ayrılığına sebep olmuştur. Çünkü şeriate göre tazir cezalarının had cezalarını aşmaması hükmü gereğince bazı hukukçular tazir cezası olarak ölüm cezası verilemeyeceğini ileri sürmüşlerdir. Ancak bazı fıkıh alimlerine göre ise toplum ve devlet menfaati gözetilerek devlet başkanlarının uygun gördükleri takdirde ölüm cezası vermelerini makul görmüşlerdir. (Başoğlu, "Tazir", s.198.; Mehmet Akif Aydın, Türk Hukuk Tarihi, Beta, İstanbul 1999, s.207-208.; Coşkun Üçok, Türk Hukuk Tarihi Dersleri, Ajans Türk Matbaası, Ankara 1957, s.72-73.; Mehmet Ali Ünal, “Osmanlı Devleti’nde Askerî Sınıfın Yargılanması", XVI. Türk Tarih Kongresi 20-24 Eylül 2010, Ankara Kongreye Sunulan Bildiriler: Osmanl Tarihi, IV. cilt, Ankara, 2015, s.677.; Mustafa Avc1, "Osmanlı Hukukunda Hapis Cezas1", Kamu Hukuku Arşivi (KHukA), V/1 (Mart 2002), s.21.; İbrahim Yılmazçelik ve Özcan Tatar, "Osmanlı Hukukunda Kısas Uygulamaları Hakkında Adana Örneğinde Bazı Tespitler: 1700-1750,” XV. Türk Tarih Kongresi, Ankara: 11-15 Eylül 2006: Kongreye Sunulan Bildiriler, c.4, 2.ks., Türk Tarih Kurumu, Ankara 2010, s.1300.

5- Mesela Suraiya Faroqhi sicillerde tecavüz, hırsızlık ve cinayet davalarına çok sık rastlanmadığını ve herhangi bir ayırım yapılmaksızın bu davaların İstanbul'a Divân'a gönderildiğini ifade etmiştir: "Bu sicillerde, ırza tecavüz, hırsızlık ve cinayet gibi daha ciddi meselelere de rastlanır ama çok sık değil. Şeriat, hırsızlığın söz konusu olmadığı cinayetlere, esasen kurbanın ailesini ilgilendiren bir mesele olarak yaklaşırken, Osmanlı Devleti para cezası ile "öşr-i diyet" denen kan parasından pay talep ediyordu. Dolayısıyla, insanlar bu tür meseleleri mahkemeye taşımadan halletmeye çalışıyorlardı. Bugünkü anlayışa göre ceza davası olarak nitelenecek pek çok durumda, kaydedilen, tanıkların anlattıklarıyla toparlanmış somut "olgular"dan ibarettir. Muhtemelen bu tür vakalar daha sonra İstanbul'daki Dîvân-1 Hümâyun'a aktarılıyordu. Ama Mühimme ve Şikâyet defterlerinden, Dîvân'ın eline bu tür dava gelince genelde ilgili kadıya şeriata uygun bir hüküm vermesi yolunda bir emir göndermekle yetindiğini anlıyoruz. Dolayısıyla, belli bir vakayla ilgili başvurulabilecek kaynaklardan hiçbirinde genelde verilen hüküm ve cezanın uygulanışı hakkında bilgi bulunmaz." (Suraiya Faroqhi, Osmanlı Tarihi Nasıl İncelenir?, Tarih Vakfı Yurt Yayınları, İstanbul 2001, s.56.) 
kesinleştiği ve infaz edildiği yönünde görüşler vardır. Ahmet Mumcu şerî davaların İstanbul'a gönderildiğini ve Divan-1 Hümayun'da görüldüğünü ifade etmiştir.6

Bazı araştırmacılar ise kadıların verdiği kısas hükmünün Bab-1 Meşihat'e gönderildiğini, tasdik olunursa Divan'da görüşülüp hakkında ferman çıkarıldıktan sonra cezanın infaz edildiğini ifade etmiştir. ${ }^{7}$

Yukarıdaki örneklerden de anlaşılacağı üzere araştırmacılar ceza davalarında yargılamanın şerî mahkemelerde yapılabileceğini fakat idam gibi ağır cezaların ancak padişah veya sadrazamın onayıyla gerçekleşebileceğini görüşündedir. $\mathrm{Bu}$ kanaat daha çok XVI. yüzyıl sicillerinde katl davalarında kadı hükümlerinin açık bir şekilde kaydedilmemiş olmasından kaynaklanmış olmalıdır.

XVI. yüzyılın ilk yarısında katl davaları ile ilgili Üsküdar kadılığı sicillerinde yaptığımız bir taramada 919-955/1515-1549 yılları arasında adam öldürme ile ilgili 58 vakanın kayıtlı olduğu tespit edilmiştir. ${ }^{8} 925$ (1519) yılına ait olan 6 hüccetten dördünün,

6- Ahmet Mumcu, Hukuksal ve Siyasal Karar Organı Olarak Divan-ı Hümayun, Birey ve Toplum Yayınları, Ankara 1986, s.98.

7- Aynı prosedürün recm ve el kesme cezalarında da uygulandığını söyleyen Avcı, Osmanlılar'da bilinen tek recm cezasının Rumeli Kazaskeri tarafından verildiğini, hükmün sadrazam tarafindan padişaha sunulduğu ve padişahın hükmü tasdik ettiğini ifade etmiştir. (Mustafa Avcı, Osmanlı Ceza Hukukuna Giriş, Mimoza Yayınları, Konya 2008, s.189.); Bu hususta hukukî prosedürü daha detaylı tarif edenler de olmuştur. Bir hukuk tarihçisi kısas hükmü verilen davaların kadılar tarafından bir ilam belgesi düzenlenerek şeyhülislamlığa sunulduğunu, şeyhülislamlıkta incelenen bu ilamların gereği altına yazılarak mahkemeye iade edildiğini, şeyhülislamlığın tasdiki bulunan bu ilamların daha sonra Divan'a gönderildiğini ve kazaskerin incelemesinden geçtikten sonra padişah iradesi olmadıkça hükmün infaz edilemediğini söylemektedir. (Mehmet Akman, Osmanlı Devleti'nde Ceza Yargılaması, Eren Yayınları, İstanbul 2004, s.118 ve 132.) Ayrıca suçun ispat edilmediği, suçun teşebbüs derecesinde kaldığı ve hüküm vermek için şartların tam oluşmadığı durumlarda da kadıların yaptıkları tahkikatı bir sicil sureti ile padişaha arz etmek zorunda olduklarını da ifade etmiştir. Ayrıca yeniçeri, sipahi ve subaşı gibi ehl-i örf, tımar veya berat sahipleri ile ilgili had ve kısas cezası gereken davalarda da aynı usulün geçerli olduğunu belirtmiştir. (Akman, Ceza Yargllamasl, s.117). H.1273-1278 (1857-1862) tarihli bir kısas defteri üzerine yapılan bir çalışmada da benzer ifadelere yer verilmiştir. Buna göre Osmanlı mahkemelerinin verdiği kısas hükmü Bab-1 Meşihate gider, tasdik olunursa Divan-1 Hümayun'da görüşülür ve ferman çıktıktan sonra infaz edilirdi. (Ahmet Aksın, Türkmen Töreli, "7 Numaralı Kısas Defterine Göre Osmanlı Şehrinde Cinayet Suçları”, Geçmişten Günümüze Şehir ve Çocuk, Ed. Osman Köse, c.I, Samsun 2016, s.475.) Bazı araştırmalarda ise ağır cezaların infazında Padişah, sadrazam, kazasker gibi üst yöneticilerin izin ve bilgisinin arandığı ifade edilmiştir. Bu uygulamanın da ceza yargılamasında ve infazda hukuk güvenliğini sağlayıcı bir işleve sahip olduğu belirtilmiştir. (Şükrü Özen, "İnfaz", DİA, 2000, c.XXII, s.291.); Yine bir hukuk tarihi çalışmasında ise cezaların infazında sadece idam değil, diğer ağır bedenî cezalara dair ilâmların da merkeze arz olunarak tasdik edildikten sonra infazın yerine getirildiği ifade edilmektedir: "Fiilen, ilâmlar, padişah değil, kazasker veya sadrazam tarafından incelenirdi, ama her halde padişah tarafından tasdik olunmak zorundaydı. Ölüm cezası içeren hükümlerin ancak padişah tasdikiyle yerine getirilebilmesi prensibi devletin sonuna kadar sürmüştür. Hatta klasik devirde çoğu zaman görülen ağır suçlara dair davalarda kadılar bir ön soruşturmacı gibi çalışarak sicilleri ve tarafları merkeze gönderip, mahkemeyi Divan bizzat yapar ve hüküm verirdi. Kadılar bilhassa taraflardan çekindikleri veya içinden çıkamadıkları davalarda bu yolu izlemeyi tercih etmişlerdir." (Ekrem Buğra Ekinci, "Osmanlı Hukukunda Mahkeme Kararlarının Kontrolü”, Belleten, CLXV/244 (2001), s.985.)

8- Taranan siciller ile ilgili ayrıntılı bilgi için bkz. Ekrem Tak, XVI.. Yüzyılda Üsküdar'da Sosyal ve İktisadi Hayatın Göstergeleri: Üsküdar Kadı Sicilleri Üzerine Bir Çalışma, Basılmamış YL. Tezi. Marmara Üniversitesi Türkiyat Araştırmaları Enstitüsü, İstanbul 2002, s.38-40. 
929 (1523) yılına ait 10 hüccetten de altısının aynı davaya ait olduğu dikkate alınırsa, Yavuz Sultan Selim'in 8 yıllık iktidarı döneminde 9 cinayetin işlendiği, Kanunî’nin ilk 8 yıllık döneminde ise 23 cinayetin işlendiği ortaya çıkmaktadır. Kânûnî’nin ilk y1llarında katl vakalarında büyük bir artış olduğu dikkat çekmektedir. Ancak Kanunî iktidarının sonraki yıllarında adam öldürme konusunda bir azalmanın olduğu ve 938 (1532) tarihinden sonra Üsküdar'ın asayiş bakımından göreceli olarak daha güvenli bir hale geldiği gözlemlenmektedir. Bu hüccetler olayın oluş ve kaydediliş şekline göre üç grupta toplanabilir. Birinci grupta ölü olarak bulunan şahısların durumunun bir kamu davası olarak takibi için kadı veya naib tarafından durumun tespiti amacıyla düzenlenmiş hüccetler yer almaktadır. Bu tür hüccetlerde hüccetin yazılma sebebi, ölen kişinin adı ve sonra maktulün ölü olarak bulunduğu yer etraflıca tarif edilmekte ve"burada maktul bulundu" veya "meyyit bulundu" cümlesi ile maktulün bulunduğu konum belirtilmektedir. Katl hüccetlerinin ikinci grubu, öldürülen kişilerin ailelerinin mahkemeye başvurmaları sonucu düzenlenmiştir. Maktul yakınları mahkemeye müracaatlarında katilin ismini vererek "yakınımızı katl etti deyu" dava açmaktadırlar. Katilin bilinmediği durumlarda yine maktül yakınlarının mahkemeye başvurarak "[yakınımız] katl olundu kâtili talep iderüz" diyerek katilin bulunması için yaptıkları müracaat kayıt altına alınmaktadır. Katl hüccetlerinin üçüncü grubu, katilin mahkemeye müracaat ederek fiilini itiraf etmesi üzerine düzenlenmiştir. Katilin bu itirafı sicillere "katl-i nefs itdüm" veya "ben katl itdüm" cümleleri ile kaydedilmektedir. İncelenen 58 katl davasında davanın sonucuna dair bir kayıt bulunmamakta, sadece durum tespiti yapılmaktadır.

Acaba gerçekten Osmanlı kadıları katl davalarında sadece tespit amaçlı kayıtlar tutup herhangi bir karar vermemişler midir? XVI. yüzyıla ait sicil kayıtlarının incelenmesi her ne kadar böyle bir görüntü verse de mühimme defterlerinde kayıtlı hükümlere ve XVI. yüzyıldan sonraki kadı sicillerine baktığımızda sadece mahkeme sicillerine bakarak bir hüküm vermenin hatalı olacağı anlaşılmaktadır. Sicillerin muhtevası yüzyıllar içerisinde değiştiğinden belli bir döneme ait siciller üzerine yapılan bir çalışmanın sonuçlarını bütün yüzyıllara teşmil etmek doğru bir yaklaşım olmayacaktır. Osmanlı hukuk tarihi çalışmalarında XVI. yüzyıla ait sicillerde had ve kısas cezasını gerektiren suçlarla ilgili kadı hükümlerine fazlaca rastlanmaması Osmanlı kadılarının bu tür davalarda hüküm verme yetkisinin olmadığına dair bir kanaatin oluşmasına sebep olmuştur. Fakat bu döneme ait sicillerde katl davalarında cezaî müeyyidelerin yer almamasına bakarak karar vermenin yanıltıcı olacağ XVII. yüzyıl ve sonrasındaki katl davalarının incelenmesinden anlaşılmaktadır. ${ }^{9}$ Nitekim mahkeme sicillerinin XVI. yüzyılda ceza davalarına ait bu sessizliği XVII. yüzyıldan itibaren yavaş yavaş değişmekte nadir de olsa kadıların karar ve hükmünü ihtiva eden kayıtlara rastlanmaktadır. Bursa kadılığının 1621-22 tarihli bir hüccetinde Yeniçeri ocağının 60. Ağa bölüğünden Musa oğlu Abdüşşekur'un eskiden beri eşkiyalık yaptığı, yol kesip ev bastığı, halkın malını yağma ettiği ve Mudurnu'da birini öldürdüğü şahitler vasitasıyla sabit olmuş ve kendisinin sâ î bi'l-fesad fi'l-arz olduğuna

9- Eyyub Şimşek, "Şer'iye Sicillerine Göre 18. Yüzyılın Başlarında Trabzon'da Yaralama ve Cinayet Vakaları", Karadeniz Incelemeleri Dergisi, Y11 8, Say1 15, Güz 2013, s.11. 
hükmedilerek hakkından gelinmesinin büyük sevap olacağ kaydedilmiştir. ${ }^{10}$

Yine 1624 yılında Yenidünya olarak tanınan Abdullah isimli şahsın birçok hırsızlıkları ve cinayetleri sabit olduğundan hakkından gelinmesi istenmiş, ${ }^{11} 1631$ yılında çobanlık yapan Durmuş'un yol kesip hırsılzlk yaptığı ve adam öldürdüğü mahkemede ayan ve eşrafın şehadetiyle sabit görülmüş ve vâcibu'l-izâle olmasından dolayı hakkından gelinmek üzere Bursa mirlivasına teslim olunmuştur. ${ }^{12}$ Bursa sicillerinde kayıtlı bulunan 1633 tarihli bir hüccette Bursa zaimi Mustafa'nın mahkemeye getirdiği Abdi isimli şahsın yol kesip eşkıyalık yaptığı ve müslümanların evlerine girerek eşyalarını çaldığı sabit olmuş ve Zaim Mustafa'nın mahkemeye getirdiği şahitler Abdi'nin suçlu olduğuna ve her şekilde ortadan kaldırılmasının çok sevap olacağına dair şehadetlerinden dolayı şer'le hakkından gelinmesine karar verilmiştir. Bu belgenin derkenarında ise bu hüccetin bir katl hücceti olduğu yazılmış ve belgenin bir suretinin de eklendiği belirtilmiştir. ${ }^{13} 1673$ 'de bir şakî Bursa'nın kuzeyinde yer alan Filadar köyündeki üzüm bağında işlediği cinayet yüzünden yargılanmış ve idama mahkum edilmiş ${ }^{14}$, 22 Cemaziyelahir 1089/11 Ağustos 1678 tarihinde yine Bursa'da öldürülen bir gencin ebeveyni kısas talep etmiş̧ir. ${ }^{15} 1679$ tarihinde Ahmed isimli bir şahsın sâ 'î bi'l-fesâd fi'l-arz olduğundan salb olunması için subaşıya tenbih ve teslim olunduğu sicile kaydedilmiştir. ${ }^{16} 1680$ senesinde Kazakoğlu diye bilinen Ali isimli şahsın ev basıp tecavüz ettiği, yol kesip adam öldürdüğü, hırsızlık yaptığı şahitlerin şehadetiyle sabit olup sâ '̂̀ bi'l-fesâd fi'l-arz olduğuna hükmedilip hakkından gelinmek üzere Muradiye subaşısına telsim edilmiştir. ${ }^{17}$ Bursa kadılığının XVII. yüzyıldaki sicillerinin de belgelediği üzere kadı Divân-1 Hümâyûn'a başvurmadan eşkiyalık ve katl davalarını doğrudan görmekte ve kâtillere ölüm cezası verebilmektedir.

İstanbul kadılarının XVIII. yüzyıla ait sicillerinde de katl cezası olarak kısas uygulamalarına ait örneklere rastlanmaktadır. Mesela, 1132 (1719-20) tarihinde öldürülen Abdurrahmân bin Mustafâ bin Mehmed'in yakınları mahkemeye müracaat ederek maktulün katili Abdullâh Beşe bin Mehmed'in yargılanmasını talep etmişlerdir. Suçlamayı inkar eden Abdullâh Beşe'nin, maktulün varislerinin mahkemeye getirdikleri şahitlerin şehadetiyle katil olduğu anlaşılmış ve hakkında aynen kısas hükmü verilmiştir. ${ }^{18}$ Üsküdar şer'iyye sicillerinde 1160 (1747) senesinde Halîl bin Mehmed'i katl eden Mustafa bin Mehmed'in suçu şahitlerin şehadetiyle sabit görülmüş ve Mustafâ'ya şer'an kısas lâzım

10- Bursa Şeriye Sicilleri (BŞS.), B.42, vr.130'den naklen Kamil Kepecioğlu, Bursa Kütüğü, Haz. Muammer Demirel ve Raşit Gündoğdu, Bursa Büyük Şehir Belediyesi, Bursa 2015, c.I, s.64.

11- BŞS., B.44, vr.44.'den naklen Kepecioğlu, c.I, s.41.

12- BŞS., B.52, vr.78'den naklen Kepecioğlu, c.II, s.7.

13- BŞS., 247, (B.53), vr.159b'den naklen Bursa Kütüğü, c.1, s.40 .

14- BŞS., B112/326, vr.12b.'den naklen Haim Gerber, “Osmanlı Hukukunda Şeriat, Kanun ve Örf 17. Yüzy1l Bursa’sı Mahkeme Kayıtları”, çev. Mehmet Akman, Hukuk Araştırmaları, VIII/1-3 (1994), s.276.

15- BŞS., B112/326, vr.12b'den naklen Gerber, s.278.

16- BŞS., B.75, vr.7'den naklen Kepecioğlu, c.I, s.74.

17- BŞS., B.104, vr.27'den naklen Kepecioğlu, c.I, s.110.

18-İstanbul Bâb Mahkemesi Şeriye Sicili (İBMŞS.), No.124, vr.28a'dan naklen Mehmet Akman, Osmanlı Ceza

Muhakemesi Hukukuna Giriş: Tanzimat Öncesi Dönem, [y.y.], İstanbul 1988, s.11. 
geldiği Dîvân'a bildirilmiştir. ${ }^{19}$ Yine aynı sene İstanbul Bâb mahkemesinde görülen diğer bir katl davasında öldürülen Yeniçeri İbrâhîm Beşe b. el-Hâc Hüseyin b. Abdullâh'ın eşi mahkemeye müracaat ederek, eşinin katili İsmâil Beşe b. Hasan'dan mûceb-i şer 'îsini talep etmiştir. Şahitlerin şehadetiyle mûcib-i kusas olduğu anlaşılan İsmâil Beşe'ye kısasen had iktizâ eylediğine hükm olunmuş ve karar Dîvân'a arz olunmuştur. ${ }^{20} 1161$ (1748) senesinde Üsküdar mahkemesinde görülen başka bir katl davasında katil ve maktülün gayr-1 müslim olduğu ve katile kısas cezası verildiği görülmektedir. ${ }^{21} 1179$ (1765) tarihinde Kostandino veled-i Foti'nin eşkıyalığı adet haline getirdiği ifade edilerek, emr-i veliyyü'l-emr gereğince katlinin meşrû olduğuna karar verilmiştir. ${ }^{22}$

Yine şahitlerin şehadetiyle kısas hükmünün verildiği bir dava da 1180 (1766) tarihinde Kasımpaşa mahkemesinde görülmüştür. Kasımpaşa'da Râbia binti Ahmed'in oğlu mahkemeye müracaat ederek annesini öldüren kayıkçı Abdî Beşe b. Mehmed'den şikayetçi olmuş ve mûceb-i şer 'îsini talep etmiştir. Abdî Beşe'nin suçunu inkar etmesi üzerine başta mahalle imamı olmak üzere diğer şahitlerin şehadetiyle Râbia'yı öldürdüğü sabit olmuş ve mûcibinin kisas olduğu Dîvân'a arz olunmuştur. ${ }^{23}$

İstanbul dışında XVIII. yüzyıl şer'iyye sicilleri üzerine yapılan muhtelif çalışmalar da kadıların katl davalarında yargılama yaptıklarını ve hüküm verdiklerini ortaya koymaktadır. Bu bağlamda 1700-1750 tarihleri arasındaki Adana şer'iyye sicilleri üzerine yapılan bir çalışma katl davalarında kısas cezasının uygulandığını gösteren örnekleri tespit etmiştir. Adana sicillerinden derlenen katl-i nefs davaları katillere kısas hükmünün verildiği 15 adet ayrı davanın varlığını ortaya koymaktadır. ${ }^{24}$

Osmanlı kadılarının verdikleri had ve kısas cezalarının sakk mecmualarında ayrıntılı örneklerinin bulunması da kadıların bu tür davalara baktıklarını ve hüküm verdiklerini belgelemek açısından önemlidir. Bilindiği gibi sakk mecmuaları tecrübeli kadılar tarafından vazifeye yeni başlayan kadılara ve naiplere rehberlik etmesi amacı ile hazırlanan ve mahkemelerin faaliyet sahasına giren konulardaki davalar için hazırlanacak hüccet, arz ya da ilam v.s. gibi belge türlerinin nasıl yazılacağına dair örnekler ihtiva eden elkitaplarıdır. Günümüze ulaşan sakk mecmuaları incelendiği takdirde bunların hemen hemen hepsinde ceza davalarına ait hükümlerin nasıl yazılacağına dair örnekler bulunabilmektedir. Osmanlının son dönemlerinde kadıların çok sık müracaat ettikleri bir mecmua olan Debbâğzâde Numân Efendi'nin (ö. 1809) Tuhfetu's-sukûk isimli

19-Üsküdar Şeriye Sicili (ÜŞS.), No. 420, vr.47a'dan naklen Deniz Akkaya, Üsküdar Kadılığı 420 Numaralı Şer'iyye Sicili Defteri 1159-1160/1747-1748, (Yayımlanmamış yüksek lisans tezi), Marmara Üniversitesi, Sosyal Bilimler Enstitüsü, 1999, s.157.

20-İBMŞS., No.192. vr.78'den aktaran Ahmet Akgündüz, Şer 'iye Sicilleri: Mahiyeti, Toplu Kataloğu ve Seçme Hükümler, Türk Dünyası Araştırmaları Vakfı, İstanbul 1989, c.II, s.112.

21-ÜŞS., No.420, vr.70a'dan naklen Akkaya, Üsküdar 420, s.229-230.

22-İstanbul Şeriye Sicili (İŞS.), No. 25, vr.53'den aktaran Yaşar Tekin, Şer'iyye Sicilleri Işı̆ğında Osmanlı Tazir Suç ve Cezaları: 1179/1765 (Yayımlanmamış yüksel lisans tezi), Marmara Üniversitesi, Sosyal Bilimler Enstitüsü,1995, s.69.

23-Kasımpaşa Şeriye Sicili, No. 58'den aktaran Tekin, Tazir, s.69-70.

24- Yılmazçelik ve Tatar, "Kısas Uygulamaları", s.1289-1325. 
mecmuasında katl davaları kısas hüccetleri başlığı altında Fasl fì hüccetü'l-kısas ve "ikrar ile sabit olan" ile "isbat ile sabit olan" şeklinde ikiye ayrılarak verilmiştir. ${ }^{25}$

Yukarıda incelenen örneklerden de anlaşılacağı üzere kadılar suçun işlendiği bölgenin yegane adlî sorumlusu olarak bütün ceza davalarına bizzat bakmaktadır. Dolayısıyla kadıların verdikleri hükmün infazı mahallinde gerçekleştirilmekte ve Divân'a bildirilme zorunluluğu bulunmamaktadır. Başka bir deyişle Osmanlı mahkemelerinin verdiği hükümler bir üst mahkemenin tasdikine ihtiyaç olmadan geçerlilik kazanmaktadır. Ancak bir itiraz durumunda davanın yeniden görülmesi için Dîvân-1 Hümâyûn yegâne makam idi. Bu durumda cezanın takdiri de Divân'a bırakılmaktaydı.

\section{Divân-ı Hümâyûn'da yargılama ve cezanın infazı meselesi:}

Bir Osmanlı mahkemesinde görülen katl davası acaba hangi durumlarda Divân-1 Hümâyûn'a intikal etmekte ve bu süreçte nasıl bir prosedür uygulanmaktadır? Kadılar acaba hangi davaları Divân'a bildiriyorlardı ve bu konuda ayrımı nasıl yapıyorlardı? Elimizdeki örneklerden hareketle bu konuda bir deneme veya tasnif yapılabilir.

Kadılara hitaben yazılmış XVI. yüzyıla ait çoğu mühimme kaydı şer'an suçu sabit olan mücrimlerin mahallinde kadı tarafından siyaset olunmasını, bunun dışındakilerin Divân'a gönderilmesini emretmektedir. ${ }^{26}$ Divân-1 Hümâyûn'un taşrada görülen davaları ve Osmanlı coğrafyasının üç kıtaya yayılmış kadılık bölgelerini merkezî olarak kontrol etmesi mümkün değildi. Kadılara bu yüzden geniş yetkiler tanınmıştı.

XVI. yüzyılın ikinci yarısına ait mühimme kayıtlarında katillerin cezalandırılmasında en çok rastlanılan ifadeler "katilin siyaset olunması" dır. "Siyaset" çoğu zaman suçlunun idamı veya katledilmesi için kullanılan bir tabirdir. "Salb ve siyaset" şeklinde de kullanılabilmektedir. Çeşme kadısına ve derya muhafazası görevinde olan Mehmed'e

25- İkrar ile sabit olan katl davasına verilen örnekte Erzurum'da Recep b. Şabân b. Abdullâh'ın öldürülmesi üzerine varisleri mahkemeye müracaat etmişler ve aynı köyden Muharrem b. Bayrâm'ı dava ederek şer 'an kısas olunmasını talep etmişlerdir. Muharrem b. Bayrâm da suçunu ikrar ederek Recep b. Şabân'1 öldürdüğünü itiraf etmiştir. Adı geçen varislerin talepleri ve verilen fetva gereğince Muharrem'in kısas olunmasına hükm olunmuştur. (Debbâğzâde Numân Efendi, Tuhfetu's-sukûk (İstanbul, 1248 [1832-33]), s.162.) Aynı mecmuanın “isbat ile olan kısas hücceti”nde ise Bağdat’ta Behzâd b. Ferhâd b. Murâd'ı öldüren Zülfikâr ibni Abbâs'ın muhakemesi kayıtlıdır. Zülfikâr önce suçu inkar etmiş, ancak şahitlerin şehadetiyle suçu sabit olunca kısasına hükm olunmuştur. Oldukça sistematik hazırlanmış bu sakk mecmuasındaki örnekler, Osmanlı kadısının katl davalarında yetkili olduğunu ve cezaî müeyyidelerin uygulanabildiği veya kısas cezasının uygulanması için davayı ilgili mercie arz ettiği görülmektedir. (Hadi Sofuoğlu, "İlm-i Sakk ve Debbağ-zâde Numân Efendi (1224/1809)'nin 'Tuhfetü’s-sukûk'u”, Dokuz Eylül Üniversitesi Illahiyat Fakültesi Dergisi, XXXV (2012), s. 197-221.

26- 7 Zilhicce 966/10 Eylül 1559 tarihli Ağriboz sancağı kadılarına gönderilen bir fermanda șer‘an suçu (cürm-i galizi) sabit olup, siyasete müstehak olanların mahallinde yargılanması bunun dışında kalan suçluların defter edilip, sicil suretleriyle birlikte Anadolu kaptanının adamına teslim olunması emredilmiştir. Fermanlarda ayrıca siyasete müstehak olanların küreğe konulmaması da sık sık tekid edilmiştir. (Mehmet İpşirli, "XVI. Asrın İkinci Yarısında Kürek Cezası İle İlgili Hükümler”, Tarih Enstitüsü Dergisi (Tayyip Gökbilgin Hatıra Sayısı), 12 (1981-82), İstanbul 1982, s.209.) 
yazılan 27 Muharrem 967 tarihli hüküm Ali isimli âmili katledip kaçanlardan bulunanların yerinde siyâset olunması ve diğerlerinin de bulunması için vakit kaybetmeden soruşturmanın başlatılması için yazılmıştır. ${ }^{27}$ İznik kadısına 13 Safer sene 967 tarihinde yazılan bir hükümde İznik〉den Akçasar'a giderken yol üzerinde öldürülen kadınların katillerinden Karamanlı Hasan hakkında İznik halkının da aleyhte şehadetleri üzerine siyâset olunması emr edilmiştir. ${ }^{28}$ Bursa beyi Bayezid beye yazılan 30 Cemâziye'l-âhir 967 tarihli hükümde katillerin yargılandıktan sonra salb u siyâset olunmaları emredilmiştir. ${ }^{29}$ 9 Receb 967 tarihinde Kavala kadısına ve kaptanına yazılan hükümde fesat çıkaran ve cinayet suçu isleyen softalar hakkında siyaset icra olunması emredilmiștir. ${ }^{30} 16$ Ramazan 967/10 Haziran 1560 tarihinde Hamideli beyine ve Uluborlu kadısına yazılan hükümde Uluborlu halkına ve hacca giden yolculara zulmeden ve hacıların mallarını zorla alan eşkıyanın yakalanarak yerinde haklarından gelinmeleri emredilmiştir. ${ }^{31}$

Katilin "sâirlerine mûcib-i ibret" ve "eşedd-i siyâset olmak" için Divân tarafından mahallinde infaz edilmek üzere İstanbul'dan suç işlediği bölgeye gönderildiği de vakidir. Çorlu kadısına 7 Rebî‘u'l-evvel 967/7 Aralık 1559 tarihinde yazılan hükümde Çorlu civarlarında hırsızlık, eşkiyalık edip ve adam öldüren Arab'ın Mısır'da yakalanması üzerine Sipahi oğlanları kethüdası ile İstanbul'a gönderilmesi ve daha sonra cezasının eşedd-i siyâset ile siyâset olunmak için mahallinde infazı emredilmiştir. ${ }^{32}$

Katl ile ilgili bazı davalarda da hadisenin kadı tarafından tescil edilip Divân'a gönderildiği "sûret-i sicilli Südde-i sa'âdet'üme ibrâz olınup arz olınmağın” ifadesinden anlaşılmaktadır. Kadı mütalaasının yazılı olarak her halükarda talep edildiği pek çok kayıtta vurgulanmaktadır.

XVI. yüzyıl Mühimme kayıtlarında askerî sınıfın ceza davalarında örfî cezalandırma şekillerinin de uygulanabildiği ve cinayete azmettirme suçundan yargılanan bir yerel askerî yöneticinin katl yerine mahiyeti açıklanmayan örfî bir cezaya çarptırıldığı görülmektedir. Şam beylerbeyine yazılan 18 Şevvâl 966 tarihli hüküm, Şam Çavuşları Kethüdası Çadırcı oğlu Mehmed'in babasını öldürtmesinden dolayı sorguya çekilmesini ve suçlunun katl olunmayıp örf-i ma 'rûf ile cezalandırılmasını şu ifadelerle emretmektedir: "Mezkûra örf-i ma'rûf idüp, kaziyye neye müncer olursa arz idesin. Ammâ katl olınup telef-i nefsden ziyâde hazer idesin, örf-i ma'rûf ile örf idesin."33 Metnin üzerinde meselenin kadiasker

$27-$

28- 3 Numaralı Mühimme Defteri (966-968/1558-1560), Haz. Nezihi Aykut vd., Başbakanlık Devlet Arşivleri Genel Müdürlüğ̈̈, Ankara 1993, s.223.

29- 3 Nolu Mühimme, s.391-392.

30- 3 Nolu Mühimme, s.402.

31- 3 Nolu Mühimme, s.548.

32- 7 Rebî‘u'l-evvel sene 967 Çorlu kadısına hüküm ki: Bundan akdem ol cevânibde harâmîlik ve hırsuzluk idüp katl-i nüfûs ve garet-i emvâl iden Arab hâliyâ Mısr cânibinde ele gelüp Südde-i sa‘âdet'üme irsâl olmağın sâ'irlerine mûcib-i ibret içün mahallinde eşedd-i siyâset olmak ecliyçün sipâhî-oğlanlarum kethüdâsı İbrâhîm zîde mecduhû ile irsâl olınup buyurdum ki: Mezkûrı ol fesâd itdüği memerr-i nâsda eşedd-i siyâset ile siyâset idüp emr-i şerîüm yirine varduğın yazup bildüresin. (3 Nolu Mühimme, s.263.)

33- 3 Nolu Mühimme, s.71. 
tarafından padişaha arz edildiği ve suçluya örf cezası uygulanmasının buyrulduğu "Kad1-asker arz idüp örf buyurıldı" ifadesiyle not edilmiştir. Hükmün kadıya değil Şam beylerbeyine yazılmış olması infaz merciinin beylerbeyi olması dolayısıyladır. Örf-i maruf ise ağır işkence anlamında kullanılmış olmalıdır.

Kadıların Divan'a gönderdiği katl davalarının mahiyetini öğrenebileceğimiz bir diğer kaynak da kürek cezaları için tutulmuş defterlerdir. Başbakanlık Osmanlı Arşivi'nde katl davalarından mahkum olanların da aralarında bulunduğu bazı suçluların Divân'da meseleleri görüşüldükten sonra küreğe konulmak üzere cezalarının tescil edildiğini bildiren kayıtların bulunduğu iki defter günümüze ulaşmıştır. Bu defterler aslında ceza davalarında uygulanan bürokratik prosedürü anlamamızı sağlayan önemli kayıtlar ihtiva etmektedir. Bunlardan ilki 970-972 tarihli olup Mehmet İpşirli tarafından neşredilmiştir. İkincisi ise 972-974 tarihlidir. ${ }^{34}$ İslam hukukunda mevcut olmayıp Osmanlılarda da ancak XVI. yüzyıl ortalarında örneklerine rastlanan kürek cezasının tesbitini hükümdar adına Divan-1 Hümayun yapmakta ve çoğu zaman bu işle kazaskerler görevlendirilmekteydi. Kadıların katl davalarında yaptığı soruşturma sonucunda suçlunun durumu, işlediği suç kadı tarafindan bir "Suret-i sicil" ile merkeze bildirilmekte ve cezanın takdiri Divan-1 hümayun'a bırakılmaktadır. Bu tür bir kaydın düzenlenişşsekli defterde şu şekilde yer almaktadir: ${ }^{35}$

“An yed-i za'im-i mahrusa-i İstanbul, ber-muceb-i arz-1 mirliva-i Kırkkilise ve suret-i sicill-i Mevlana Siyami Kadi-yı Havass-1 Mahmud Paşa. Amed fî 25 Şa〉ban sene 970.

Suret-i sicili ve arzı kisede mahfuzdur.

1- Murad veled-i Tanrıvirmiş

2- Ahmed b. Mehmed

3- Ramazan b. Mehmed

4- Yusuf b. Abdullah

Haliya Babaeskisi'ne tabi’ Söğütlüdere kurbunda vakı' olan maktul Mahmud'un ahvali tefahhus olundukda Kırkkilise'ye tabi' Hasköy kurbunda Mahrusa-i İstanbul'dan Edirne'ye giden yolculardan mezbûr Murad üç nefer yoldaşı ile tutulup, su'al olundukda mezbur Murad, maktûl

\footnotetext{
34- Başbakanlık Osmanlı Arşivi’nde Mehmet İpşirli tarafından neşredilen defterden başka kürek cezası ihtiva eden bir defter daha bulunmaktadır. 972-974 tarihleri arası hükümleri ihtiva eden bu defter MAD.23135 numarada kayıtlı olup küreğe gönderilen suçlularla ilgili kayıtları ihtiva etmektedir. Bu defter ceza davalarına konu olmuş çok farklı suçları ihtiva etmektedir: Kadı veled-i Tanrıvermiş: Ereğli kadılığından olup avret ile dutulup Bayezid beğ göndermiştir. (Başbakanlık Osmanlı Arşivi (BOA), MAD.23315, s.7.); Şah Bali: Mezkûrun elinde üç yüz kalp akçe bulunduğu ecilden habs olunup küreğe gönderilmiștir. (BOA, MAD.23315, s.16.); Cihan Neşad: Mezkûr Ladik'ten olup kadısı ile mücâdele idüp şirret eyledüği ecilden küreğe gönderilmiştir. (BOA, MAD.23315, s.16.); Karaderviş Kemal: Mezkûr yankesiciliğiyle meşhûr olup ol sebepden habs olunup küreğe gönderildi. (BOA, MAD.23315, s.17.); Dimitri Yani: Mezkûr oğlan 1zlâl itdüği müseccel olmuşdur. (BOA, MAD.23315, s.19)

35- İpşirli, "Kürek Cezası”, s.208.
} 
olan Mahmud'ı su yanında otururken başına değnek ile urup, «Ben katl eyledim» diyüp i’tiraf itdikde salb olunup, birisi gaybet edip ikisi küreğe gönderildi."

Belgeden anlaşıldığına göre Murad adlı şahıs üç arkadaşı ile Babaeski’ye bağlı Sögütlüdere yakınlarında Mahmud'u öldürmüş, yapılan araştırma sonucunda Hasköy yakınlarında yakalanmışlardır. Suçunu itiraf eden Murad asılmış, birisi kaçmış diğer ikisi ise küreğe konulmak üzere Mahmud Paşa mahkemesi sicili ile Divân’a gönderilmiştir.

Taşrada şehzadelerin görev sahalarına giren bölgelerde vuku bulan ve cezai müeyyide gerektiren suçlar ise Şehzade divanlarında görülmekte ve burada tutulan defterlere kaydedilmekteydi. Bu defterlerden günümüze sadece birkaç tanesi ulaşmış olup bunlardan bir tanesi Şehzade divânının yargı yetkileri bakımından Feridun Emecen tarafından incelenmiştir. ${ }^{36}$ Konumuz itibari ile defterde kayıtlı bulunan katl ile ilgili davalara baktığımızda kısas ya da suçun niteliğine göre siyaset (idam) ve hapis cezası gerektiren katl hadiselerinin az sayıda divana intikal ettiği görülmektedir. Bununla birlikte bu davalarda genel itibariyle kürek cezaları ağırlık kazanmaktadır.Deftere yansıyan 15 katl konulu davanın dokuzunda suçluya kürek cezası verilirken, 6 suçlunun da siyaset olunmasına karar verilmiştir. ${ }^{37}$

\section{Katl davalarında cezaların infazı:}

Osmanlı hukukunda cezaların infazı taşra ve merkezde farklı yetkililer tarafından gerçekleştiriliyordu. Taşrada infaz subaşılar tarafından gerçekleştirilirken merkezde suçun işlendiği mahalle göre değişen ve çeşitlenen infaz mercileri ortaya çıkmaktadır. Ceza ve kısas davalarında kadıların yetkili olduğunu ve infazların mahallinde subaşılar vasıtasıyla gerçekleştirildiğini gösteren bir belge konumuz bakımından önem taşımaktadır. Bursa sicillerinde yer alan Evâil-i Cemâziyelâhir 939 (29 Aralık 1532-7 Ocak 1533) tarihli bu belge ceza davalarının kadılar tarafından görüldüğünü ve subaşıların yargı sürecinden sonra idamları gerçekleştirdiklerini bildirmektedir. ${ }^{38}$ Metinden anlaşıldığına göre subaşılar suçluları asmanın yanı sıra herhangi bir uzvun kesilmesi ve el kesme yetkisine de sahiptirler.

36- İncelenen defter Başbakanlık Osmanlı Arşivi ADVN. nr.794'de kayıtlı olup II. Mehmed'in Manisa'da şehzadeliği dönemine ait 997-1003/1588-1594 yılları arasındaki tayin, terakki, asayiş, mali ve bazı hukuki konular ile ilgili kayıtları ihtiva etmektedir. (Feridun Emecen, "Şehzade Divanında Suç ve Ceza", Marmara Üniversitesi Hukuk Fakültesi Hukuk Araştırmalarl Dergisi, Prof. Dr. Mehmet Akif Aydın'a Armağan Özel Sayısı, c.XXI/2 (2015), s.55-92.)

37- Defterde kürek cezası verilen suçlulara ait hükümler, gönderilecekleri sancağın beyine hitaben yazılarak kaydedilmiştir. Defterdeki kayıtlardan bu dönemde kürek cezasına çarptırılan suçluların Cezayir-i Bahr-i Sefid beylerbeyliğine bağlı sancaklara gönderildikleri anlaşılmaktadır. Haklarında siyaset kararı verilenler ise herhangi bir yere nakledilmedikleri için haklarındaki hüküm "siyaset olunmak ferman olunmağın kayd olundu" şeklinde bitirilmektedir. (Emecen, s.59-60.)

38- Halil İnalcık, "Osmanlı İdare, Sosyal ve Ekonomik Tarihiyle İlgili Belgeler Bursa Kadı Sicillerinden Seçmeler (III. Köy Sicil ve Terekeleri)”, Belgeler, XV/19 (1993), s.46. 


\section{“Hazreti’l-mevâliyi'l-mükerremûn}

Be-cenâb-1 mecâlis-i emâcid-i kirâm ve mahâfil-i efâzıl-1 enâm el-mahsûs bi-inâyeti'l-meliki'l-allâm el-hâkimûne'l-âmilûn be-kazâ-i Atranos ve Kebsûd ve Kirmasti edâmallahu fezâyilehüm ba'de envâi'ttahiyye ve't-teslîm bi'l-i'zâz ve't-tefhîm izz-i huzurlarınıza i'lâm olunan budur ki el-hâletü hâzihî işbu resânende-i hurûf adamımız Mustafa’nın kemâl-i emânetine ve hüsn-i istikâmetine i'timâdımız olduğu sebebden zikr olunan kadılıklarda bu cânibe âid olan mahsûlâtı ve mersûmâtı vesâir cerâyimi îcâb-1 şer' ve kanun üzere zabt ve hıfz eylemek için subaşı ta'yîn olunup irsâl olunduğu bundan akdem vâki‘ olan za'îmler her ne vechile tasarruf edegelmişler ise bu dahi ol minvâl üzere mutasarrıf olup salbe ve kat'-l uzva ve kat'-l yede müstehakk olanlarl siz hâkimü'l-vakt ma 'rifetiyle sicillât eyleyüp kânûn-ı padişâhî mûcibince istihkâklarına göre siyâsetlerin eyleyüp haklarından gele hılâf-1 şer' ve kânûn kimesne dahl ve ta'arruz eylemeye şöyle bilesiz. Tahrîran fî̀ evâil-i Cemâziye'l-âhir sene tis'a ve selâsîn ve tis'a-mie"

Belge eyalet beylerbeyi tarafindan Atranos, Kepsut ve Kirmasti kadılarına hitaben gönderilmiştir. Belgeden anlaşıldığına göre kadılar her türlü davada olduğu gibi katl davalarında da hüküm vermeye ve infazın gerçekleştirilmesi için subaşıları görevlendirmeye doğrudan yetkiliydiler. Osmanlı hukuku yargı ve infaz yetkisini tek elde toplamamıştır. Buna bağlı olarak da infazları gerçekleştiren subaşılar, şerî hukukun temsilcisi olan kadıların yerine örfî hukukun temsilcisi olan beylerbeyi ve sancak beyinin denetiminde bulunmuştur. Belge, mahkeme prosedürünün kadılar tarafından yerine getirildikten sonra kayıt altına alınmasını (sicillât eyleyüp) ve subaşının bu aşamadan sonra infâzı gerçekleştirmesini (kânûn-1 pâdişahî mûcibince istihkâklarına göre siyâset eyleyüp) emretmektedir.

Evliyâ Çelebi de İstanbul'da cezaları infaz etme yetkisine sahip görevlileri sayarken subaşıların bir yargı faaliyeti sonunda suçluları infaz ettiğini ve ölüm cezasına çarptırılanların "izn-i şer "ile salb u siyâset" edildiğini söylemektedir:

“Onuncu hâkim: Subaşıdır. Gerçi bunlarda cellâdlar ve kırbaç ve tâziyâneler vardır amma falaka deynekleri yokdur. Lâkin mazannaları olduğu kimesneleri kayd [u] bend etmeğe ve mahkeme naibiyle ba' $\mathrm{z} 1$ hanedanları basmağa me'mûrlardır. Ve her katl etdüklerin izn-i şer'ile salb [u] siyâset ederler." 39

Evliyâ Çelebi İstanbul'daki kaza (yargı) mercileri ile cezaları infaz etmekle görevli kimseleri "Hîn-i fethinde İstanbul'da hâkim nasb olunanlar" başlı̆̆ 1 altında incelemiş ve bunları infaz yetkileri bakımından değerlendirmiştir. Evliyâ Çelebi İstanbul'da ilk olarak

39- Evliyâ Çelebi bin Derviş Mehmed Zılli, Evliyâ Çelebi Seyahatnamesi, Topkapı Sarayı Kütüphanesi, Bağdat 304 Numaralı Yazmanın Transkripsiyonu Dizini, Haz. Yücel Dağlı vd., Yapı Kredi Yayınları, İstanbul 2003 , I. Kitap, s.53. 
vezîr-i a'zam Mehmed Paşa'ya beş cellâd, bir yeniçeri odası, muhzır ağa, sipâh kethudâ yerleri, cebeci, topçu, azebistân çavuşları, bir bostancı odabaşısı, yeniçeriden bir tüfengci ve bir mataracı verildiğini söyleyip İstanbul'da sadrazamların kol gezerek şehirde esnafı teftiş ettiğini bildirmekte ve "Unkapanı'nda bina olunan ehl-i hıref dîvânhanesine gelüp dîvân" ettiğini ifade etmektedir. Bu metinden anlaşıldığına göre sadrazamlar suçluları infaz yetkisine sahip en üst ve yetkili makam olup Sadrazam Mehmed Paşa infaz yetkisini maiyetindeki beş cellad vasıtasıyla uygulamaktadır. ${ }^{40}$

İstanbul'da görev alanları belli bir bölgeyle sınırlandırılmış bulunan devlet memurlarının da suçluları suçun türüne göre cezalandırma yetkileri vardı. Mesela Çorbacıyân denilen on iki yeniçeri çorbacısı gece kol gezip yakaladıkları suçluları cezalandırabilmekteydi. Mimarbaşının kendinden habersiz bina yapanları tazir ile cezalandırma yetkisi vardı. Tersane kethüdası da Kasımpaşa'da yakalanan suçluları tazir etme ve hatta suçun derecesine göre idam etmeye yetkiliydi. Kaptan Paşa ise sadece denizde vuku bulan olaylara bakardı. Okmeydanı'nda Yeniçeri Ocă̆ı'nda bulunan ta 'lîmhânecibaşı ve korucular Okmeydanı sınırları içerisinde yakaladıkları suçlulara suçun türüne göre tazirden idama kadar her türlü cezayı verebilirlerdi. Evliyâ’nın aktardığına göre bu korucular suçluları yayların çilesiyle ağaca asarak idam etme yetkisine de sahiptiler. ${ }^{41}$

\section{Sonuç}

Osmanlı ceza yargılamasıyla alakalı olarak kadı sicillerine ve mühimme defterlerine yansıyan örneklerden de anlaşılacağı üzere kadılar suçun işlendiği bölgenin yegane adlî sorumlusu olarak bütün ceza davalarına bizzat bakmaktadır. Dolayısıyla kadıların verdikleri hükmün infazı mahallinde gerçekleştirilmekte ve Divân'a bildirilme zorunluluğu bulunmamaktadır. Osmanlı mahkemelerinin verdiği hükümler bir üst mahkemenin tasdikine ihtiyaç olmadan geçerlilik kazanmakta, ancak bir itiraz ve gereklilik durumunda dava Dîvân-1 Hümâyûn'da yeniden görülmektedir. Bu durumda cezanın takdiri de Divân’a bırakılmaktaydı.

Bütün katl davalarının Osmanlı coğrafyasının tamamından Dîvân-1 Hümâyûn'a gönderilmesi ve bütün davaların Dîvân'da görüşülüp karar verilmesi imkan dışıdır. Gerek kadı sicilleri gerekse Divân-1 Hümâyûn defterleri üzerine yapılan incelemeler kadıların bu tür davalarda tek yetkili olduğunu ve şerî hukuka göre had ve kısas cezaları verdiklerini göstermektedir. İslam mahkemelerinin en önemli özelliği olan tek hâkimli mahkeme sistemi Osmanlılar tarafından da benimsenmiş ve XIX. yüzyıla kadar uygulama bu şekilde devam etmiştir.

40- Evliyâ Çelebi, Seyahatname, I. Kitap, s.53.

41- Evliyâ Çelebi, Seyahatname, I. Kitap, s.53. 


\section{Kaynakça}

3 Numaralı Mühimme Defteri (966-968/1558-1560), Haz. Nezihi Aykut vd., Başbakanlık Devlet Arşivleri Genel Müdürlüğü, Ankara 1993.

Akgündüz, Ahmet, Şer 'iye Sicilleri: Mahiyeti, Toplu Kataloğu ve Seçme Hükümler, Türk Dünyası Araştırmaları Vakfı, İstanbul 1989, c.II.

Akkaya, Deniz, Üsküdar Kadılığı 420 Numaralı Şer'iyye Sicili Defteri 1159-1160/17471748, (Yayımlanmamış yüksek lisans tezi), Marmara Üniversitesi, Sosyal Bilimler Enstitüsü, 1999.

Akman, Mehmet, Osmanlı Ceza Muhakemesi Hukukuna Giriş: Tanzimat Öncesi Dönem, [y.y.], İstanbul 1988.

Osmanlı Devleti'nde Ceza Yargılaması, Eren Yayınları, İstanbul 2004.

Aksın, Ahmet, Töreli, Türkmen, "7 Numaralı Kısas Defterine Göre Osmanlı Şehrinde Cinayet Suçları”, Geçmişten Günümüze Şehir ve Çocuk, Ed. Osman Köse, c.I, Samsun 2016, s.475-489.

Avc1, Mustafa, “Osmanlı Hukukunda Hapis Cezası”, Kamu Hukuku Arşivi (KHukA), V/1 (Mart 2002), s.19-35.

Osmanlı Ceza Hukukuna Giriş, Mimoza Yayınları, Konya 2008.

Aydın, Mehmet Akif, Türk Hukuk Tarihi, Beta, İstanbul 1999.

Bardakoğlu, Ali, “Ceza”, Türkiye Diyanet Íslam Ansiklopedisi (DİA), 1993, c.VII, s.470478.

Başoğlu, Tuncay, "Tazir”, DİA, 2011, c.XL, s.198-202.

Dağc1, Şamil, “Kısas”, DİA, 2002, c.XXV, s.488-495.

Debbâğzâde Numân Efendi, Tuhfetu's-sukûk, İstanbul 1248 [1832-33].

Ekinci, Ekrem Buğra, “Osmanlı Hukukunda Mahkeme Kararlarının Kontrolü”, Belleten, CLXV/244 (2001), s.959-1005.

Emecen, Feridun, "Şehzade Divanında Suç ve Ceza", Marmara Üniversitesi Hukuk Fakültesi Hukuk Araştırmaları Dergisi, Prof. Dr. Mehmet Akif Aydın'a Armă̆an Özel Sayıs, c.XXI/2 (2015), s.55-92.

Evliyâ Çelebi bin Derviş Mehmed Zılli, Evliyâ Çelebi Seyahatnamesi, Topkapı Sarayı Kütüphanesi, Bağdat 304 Numaralı Yazmanın Transkripsiyonu Dizini, Haz. Yücel Dağlı vd., Yapı Kredi Yayınları, İstanbul 2003, I. Kitap.

Faroqhi, Suraiya, Osmanlı Tarihi Nasıl Incelenir?, Tarih Vakfı Yurt Yayınları, İstanbul 2001.

Gerber, Haim, “Osmanlı Hukukunda Şeriat, Kanun ve Örf 17. Yüzyıl Bursa’sı Mahkeme Kayıtları”, çev. Mehmet Akman, Hukuk Araştırmaları, VIII/1-3 (1994), s.265-291. 
İnalcık, Halil, "Osmanlı İdare, Sosyal ve Ekonomik Tarihiyle İlgili Belgeler Bursa Kadı Sicillerinden Seçmeler (III. Köy Sicil ve Terekeleri)”, Belgeler, XV/19 (1993), s. $23-167$

İpşirli, Mehmet, “XVI. Asrın İkinci Yarısında Kürek Cezası İle İlgili Hükümler”, Tarih Enstitüsü Dergisi (Tayyip Gökbilgin Hatıra Sayısı), 12 (1981-82), İstanbul 1982, s.203-248.

Kepecioğlu, Kamil, Bursa Kütüğ̈̈, Haz. Muammer Demirel ve Raşit Gündoğdu, Bursa Büyük Şehir Belediyesi, c.I., Bursa 2015.

Mumcu, Ahmet, Hukuksal ve Siyasal Karar Organı Olarak Divan-ı Hümayun, Birey ve Toplum Yayınları, Ankara 1986.

Özen, Şükrü, “İnfaz”, DİA, 2000, c.XXII, s.290-292.

Sofuoğlu, Hadi, “İlm-i Sakk ve Debbağ-zâde Numân Efendi (1224/1809)’nin 'Tuhfetü’ssukûk’u”, Dokuz Eylül Üniversitesi Ilahiyat Fakültesi Dergisi, XXXV (2012), s.197-221.

Şimşek, Eyyub, “Şer’iye Sicillerine Göre 18. Yüzyılın Başlarında Trabzon'da Yaralama ve Cinayet Vakaları", Karadeniz Incelemeleri Dergisi, Y11 8, Sayı 15, Güz 2013, s.9-26.

Tak, Ekrem, XVI.. Yüzyılda Üsküdar'da Sosyal ve İktisadi Hayatın Göstergeleri: Üsküdar Kadı Sicilleri Üzerine Bir Çalışma, Basılmamış YL. Tezi. Marmara Üniversitesi Türkiyat Araştırmaları Enstitüsü, İstanbul 2002.

Tekin, Yaşar, Şer‘iyye Sicilleri Işığında Osmanlı Tazir Suç ve Cezaları: 1179/1765 (Yayımlanmamış yüksel lisans tezi), Marmara Üniversitesi, Sosyal Bilimler Enstitüsü,1995.

Üçok, Coşkun, Türk Hukuk Tarihi Dersleri, Ajans Türk Matbaası, Ankara 1957.

Ünal, Mehmet Ali, “Osmanlı Devleti’nde Askerî Sınıfın Yargılanması”, XVI. Türk Tarih Kongresi 20-24 Eylül 2010, Ankara Kongreye Sunulan Bildiriler: Osmanlı Tarihi, IV. cilt, Ankara, 2015, s.669-697.

Yılmazçelik, İbrahim, Tatar, Özcan, “Osmanlı Hukukunda Kısas Uygulamaları Hakkında Adana Örneğinde Bazı Tespitler: 1700-1750," XV. Türk Tarih Kongresi, Ankara: 11-15 Eylül 2006: Kongreye Sunulan Bildiriler, c.4, 2.ks., Türk Tarih Kurumu, Ankara 2010, s.1289-1325. 